\title{
HIF1A wt Allele
}

National Cancer Institute

\section{Source}

National Cancer Institute. HIF1A wt Allele. NCI Thesaurus. Code C52040.

Human HIF1A wild-type allele is located within 14q21-q24 and is approximately $53 \mathrm{~kb}$ in length. This allele, which encodes hypoxia-inducible factor 1 alpha protein, is involved in angiogenesis and transcriptional regulation during the cellular adaptive response to hypoxia. Overexpression of the HIF1A gene is associated with several types of cancer such as hepatocellular carcinoma and renal cell carcinoma. 